\title{
FURTHER OBSERVATIONS OF THE RUFFED GROUSE'S "CRAZY-FLIGHT"
}

\section{VICTOR C. FRIESEN, P.O. Box 65, Rosthern, Saskatchewan SOK 3 R0}

It is seven years since I first reported my observations concerning the "crazy-flight" of the Ruffed Grouse. This flight refers to the bird's occasional mode of flying wildly about, often against buildings, and sometimes killing itself.

In my article I discussed the findings about this phenomenon, from reports dating back to the early 1800 's (those of Audubon) and extending to the middle of our present century. Reference was made to studies by Hall, Bump, Edminster, Knight, and Grange, all of whom published their findings in 1946-48. Earlier works cited, besides Audubon's, were by Allen, Bent, Forbush and Gross. (Full bibliographical information on these studies can be referred to in that article).

What was apparent from these findings was that they did not agree on any one explanation for the crazyflight phenomenon. Explanations given included population pressure, migration instinct, disease, change of diet, sudden fright, nervousness caused by sparse cover, and color of the object against which the bird flew. No one of these reasons adequately explained all six of my observations from 1963 to $1968 .^{2}$

Now, further studies have come to my attention - some previously overlooked, some new - and I myself have five more observations to report. For review, all 11 of my observations are summarized in Table 1 . The new observations will be described in some detail in the latter part of this article.

\section{Survey of Literature}

The studies not previously reported are here treated chronologically. Not all of them speak directly of the cause of the crazy-flight, but the comments do have some bearing on the phenomenon. Trippensee implied that crazy flights were something apart from seasonal movements, for the latter, he said, were of shorter distance, usually less than one mile.' Chambers and Sharp found, however, that most juveniles tended to move farther than a mile during dispersal, thus suggesting in the light of some other observers' comments that fall dispersal and the crazy flight might be related. ${ }^{\prime}$

It is to be remembered that Seton in his classic Wild Animals I Have Known had detailed the true account of a particular Ruffed Grouse and made some observations about the species generally. ${ }^{6}$ He had said that all Ruffed Grouse in their first year, and to a lesser extent in their second year but practically never thereafter, go crazy in the autumn. They fly into strange territory in their "mad hankering to get away somewhere", and this craze has at least the effect of breaking up families and preventing inbreeding. Chambers and Sharp, too, saw that adults, after their first mating season, remained relatively sedentary. 'While another study made no particular mention of the crazy-flight, this project of banding grouse in Wisconsin did note the fall movement of juveniles. ${ }^{4}$ This, the authors, said, was independent of population pressure.

Farther west, in Minnesota, a detailed study centered on two broods 


\begin{tabular}{|c|c|c|c|c|c|c|c|}
\hline Season & Date & Time & Skies & $\begin{array}{l}\text { Position } \\
\text { of Sun }\end{array}$ & $\begin{array}{l}\text { Tempera- } \\
\text { ture }\end{array}$ & Wind & $\begin{array}{l}\text { Height } \\
\text { of } \\
\text { Impact }\end{array}$ \\
\hline 1) Spring & $\begin{array}{l}\text { April, } \\
1963\end{array}$ & - & - & - & - & - & - \\
\hline 2) Spring & $\begin{array}{l}\text { April, } \\
1963\end{array}$ & $\begin{array}{l}\text { Early } \\
\text { evening }\end{array}$ & Clear & Behind & Cool & Calm & $1-2 \mathrm{ft}$. \\
\hline 3) Spring & $\begin{array}{l}\text { May, } \\
1964\end{array}$ & $\begin{array}{l}\text { Mid- } \\
\text { morning }\end{array}$ & Clear & In front & Warm & Calm & $1-2 \mathrm{ft}$. \\
\hline 4) Summer & $\begin{array}{l}\text { Aug., } \\
1964\end{array}$ & $\begin{array}{l}\text { Mid- } \\
\text { afternoon }\end{array}$ & Clear & Behind & Cool & Calm & $1-2 \mathrm{ft}$. \\
\hline 5) Spring & $\begin{array}{l}\text { May, } \\
1966\end{array}$ & $\begin{array}{l}\text { Early } \\
\text { evening }\end{array}$ & Clear & From side & Warm & Calm & - \\
\hline 6) Fall & $\begin{array}{l}\text { Sept., } \\
1968\end{array}$ & Evening & - & Had set & Cool & Calm & - \\
\hline $\begin{array}{l}\text { 7) Late } \\
\text { spring }\end{array}$ & $\begin{array}{l}\text { June } 13 \\
1973\end{array}$ & 4:00 p.m. & Hazy & Behind & $20^{\circ} \mathrm{C}$ & Gusty & $1-2 \mathrm{ft}$. \\
\hline $\begin{array}{l}\text { 8) Late } \\
\text { spring }\end{array}$ & $\begin{array}{l}\text { June } 14 \\
1973\end{array}$ & $6: 45$ a.m. & Hazy & In front & $10^{\circ} \mathrm{C}$ & Breezy & $1-2 \mathrm{ft}$ \\
\hline 9) Fall & $\begin{array}{l}\text { Oct. 5, } \\
1975\end{array}$ & 5:00 p.m. & Hazy & Behind & $17^{\circ} \mathrm{C}$ & Calm & $5 \mathrm{ft}$. \\
\hline $\begin{array}{l}\text { 10) Spring } \\
\text { or fall }\end{array}$ & $1960-65$ & $\begin{array}{l}\text { Mid- } \\
\text { morning }\end{array}$ & Clear & Behind & - & - & $5 \mathrm{ft}$. \\
\hline 11) Winter & $\begin{array}{l}\text { Jan. 21, } \\
1978\end{array}$ & 9:00 a.m. & Clear & Not risen & $-18^{\circ} \mathrm{C}$ & Calm & $5 \mathrm{ft}$ \\
\hline
\end{tabular}

of Ruffed Grouse with nine juveniles. ${ }^{3}$ Dispersal was recorded by radio transmitters on some birds. In the fullest explanation yet, these authors concluded that crazy-flight behavior "is explained as the probable manifestation of typical dispersal activity" and that dispersal occurs "as a definite yearly activity" and "not merely [as] a mechanism of scattering surplus grouse." All dispersal took place in four days or less - with an average distance of 1.85 miles. Each grouse, by walking as well as flying, tended to travel in one direction so that placement of buildings and other obstructions in its way could well lead to the characteristic casualties associated with crazy-flight. Of course, these casualties, the writers continued, would be more noticeable during times of high grouse population and so give rise to the notion that population pressure instigated them.
More recently, Woolner repeated the idea that overcrowding is not the cause of crazy-flights, and he, too, saw the flight as a distinct fall occurrence with the majority of birds killed being immatures. $^{8}$ In a book addressed chiefly to hunters, he came to the same conclusion as did Seton and spoke in this manner of nature's way of spreading a brood and getting new blood into different areas: "Crazy flight is a transitional madness, the natural rebellion of the young that courts disaster as it bridges the dangerous gap between youth and adulthood." At the same time he also voiced the idea that crazy grouse may be feeding on hallucinatory fungi (the drug scene invading the world of the grouse!)

In another general study of the Ruffed Grouse, the annual fall shuffle was linked with their crazy-flight but 
no definite answer as to the exact cause was provided. ${ }^{5}$ Incidents were noted however, of the aggressiveness of cock grouse - their attacking a man by grabbing a pant leg and shaking it or their attacking their own image in a car's hubcap or windshield. Also described was the well-known propensity of grouse in winter for flying head-first into snowdrifts and then spending the night there. Both of these activities, as we shall see later, may have some relation to the crazyflight phenomenon.

\section{Local Observations}

Of my five new observations, three were made by myself and two by a neighbor. With these apparent crazyflights, I have taken more pains than before in compiling notes, realizing that any details, including weather data, may prove significant at some future time when more information is available concerning this phenomenon. Again, as in my previous article, the observations were made on our farmyard 3 miles east of Rosthern, Saskatchewan, or on a yard immediately adjoining our quartersection. Both yards have rows of shade trees along which grouse walk when leaving their covert in nearby poplar bluffs.

Five years had passed since my last reported observation in 1968 . Then in June, 1973, two grouse flew into our house on successive days, recalling for me my observations 10 years earlier when two grouse met their death there just a few days apart in the month of April. Although I had also previously recorded two crazy-flights occurring in May, one in August and one in September, this was the first I had witnessed in June.

It occurred on June 13, at 4:00 p.m. There was a hazy sun, a strong gusty wind from the east, and a temperature of $20^{\circ} \mathrm{C}$. The bird hit the northwest corner of our house on the west side,
1.5 feet above ground, while I was standing out of sight nearby. It got up dazed and limped to the north side of the building where it died 15 minutes later. Examation revealed it to be a nesting female! - the brood spot on its lower breast was without feathers (Fig. 1). Females generally lay an egg each morning and spend the rest of the day feeding until the clutch is completed; then brooding begins.

I mentioned in my earlier article that our house is painted white, and there is some evidence to suggest that such walls may appear as sky to a Ruffed Grouse. ${ }^{2}$ However, the walls of our house are covered with clapboards so that this "sky" would look quite artificial, being ruled out in neat horizontal lines. In such manner it must have appeared to various grouse throughout the 1940 's and ' 50 's, for no collisons occurred then, and there is no reason to believe that it should look any different to them in the last two decades. Furthermore, this female grouse hit the corner just beside a vertical trim board painted green.

At 6:45 a.m. the next day another thud told of a second collision, again on the west wall but at the other corner. At this early morning period the weather conditions were similar to those of the day before - a hazy sun, a breeze from the east, and a temperature of $10^{\circ} \mathrm{C}$. A slight smear on the wall showed the point of impact, once more 1.5 feet from the ground. A single Ruffed Grouse feather was found nearby.

Later that morning, at 9:30, I made a thorough investigation of the lilacs growing near the house to see if I could find the bird. Forty feet away I flushed a grouse from a carragana hedge that borders our lane. From its somewhat labored flight, I believed it to be the bird which hit our house.

It can be said that in both these collisions the sunlight, either direct or 


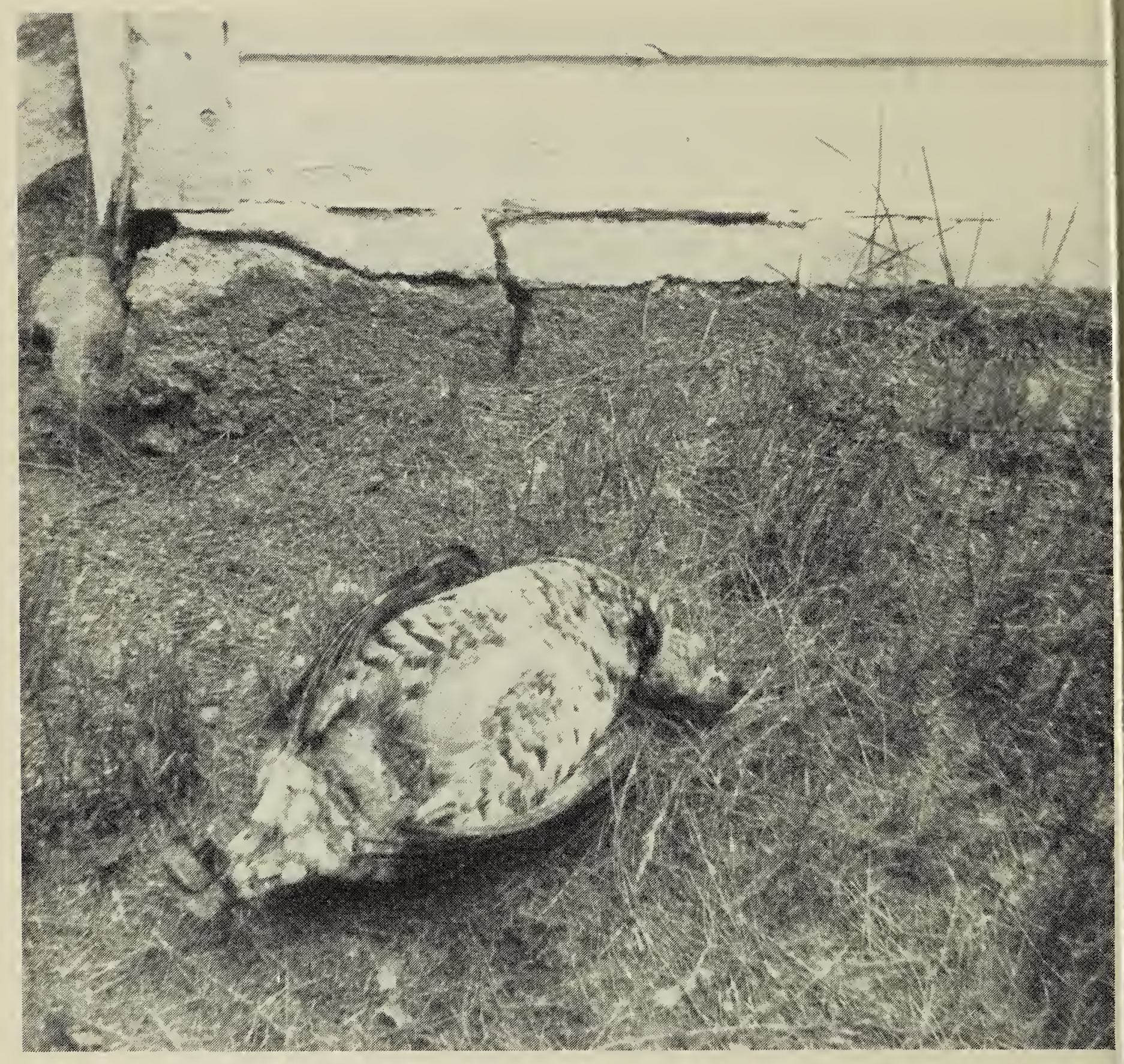

V. C. Friesen

Fig. 1: Nesting Ruffed Grouse, killed in collision with house, June 13, 1973

reflected from the wall, would not have hindered the grouse's vision. In the first instance what sun there was, was behind the bird; in the second instance the rising sun's rays were blocked out by a bush.

I had one further occasion to witness a crazy-flight, this time from its start to its finish, as I had done once before in August, 1964. The grouse in question did seem to be agitated before it began its flight. In later afternoon, October 5, 1975 - a sunny day with some haze, no wind and a temperature of $17^{\circ} \mathrm{C}-$ I heard a Ruffed Crouse walking up and down in the dried leaves at the edge of a poplar bluff just west of our yard. It was making "cooing" noises. When I stepped into view and we saw each other for the first time, the bird continued to strut and to coo 25 feet away

Then the grouse whirred its wings and took off - at me. Audubon had reported that male grouse in jealousy sometimes fly at man if the person imitates the bird's drumming sound, and a related experience was noted above. ${ }^{25} \mathrm{l}$, however, was standing as still as possible. Since I had been watching the grouse intently, I could distinctly see it close its eyes on taking off - white eyelids replacing its dark 
eyes - but the bird opened them again while just under way.

All these things, of course, happened in a matter of moments. I tried to dodge aside, and the grouse veered the other way, flying along a row of pruned maples which forms the northern boundary of our yard. Then it veered inside, between two trees, glided along a fifty-foot building (painted red), rounded the corner, and with a further whir of wings safely steered its course between two more maples of a north-south row before our house. Then it crashed through the house's west bedroom window - both the storm and regular windows. Only a dresser inside prevented it from hurtling across the entire room (Fig. 2).

My mother had been walking to the door to go inside when the grouse made its own entrance, just six feet away. We do not know whether the grouse noticed her. The accompanying photograph shows that the window may have looked like sky to the bird, but at the time of impact a creamcolored blind was drawn inside, eliminating the reflection.

Surprisingly, the grouse was not killed. It was found on a bed, and, while being carried outside, it struggled but it did not move when placed on the lawn. It squatted there for an hour, in spite of my activity

Fig. 2: The grouse survived this collision with a double window, October 5, 1975

V.C.Friesen

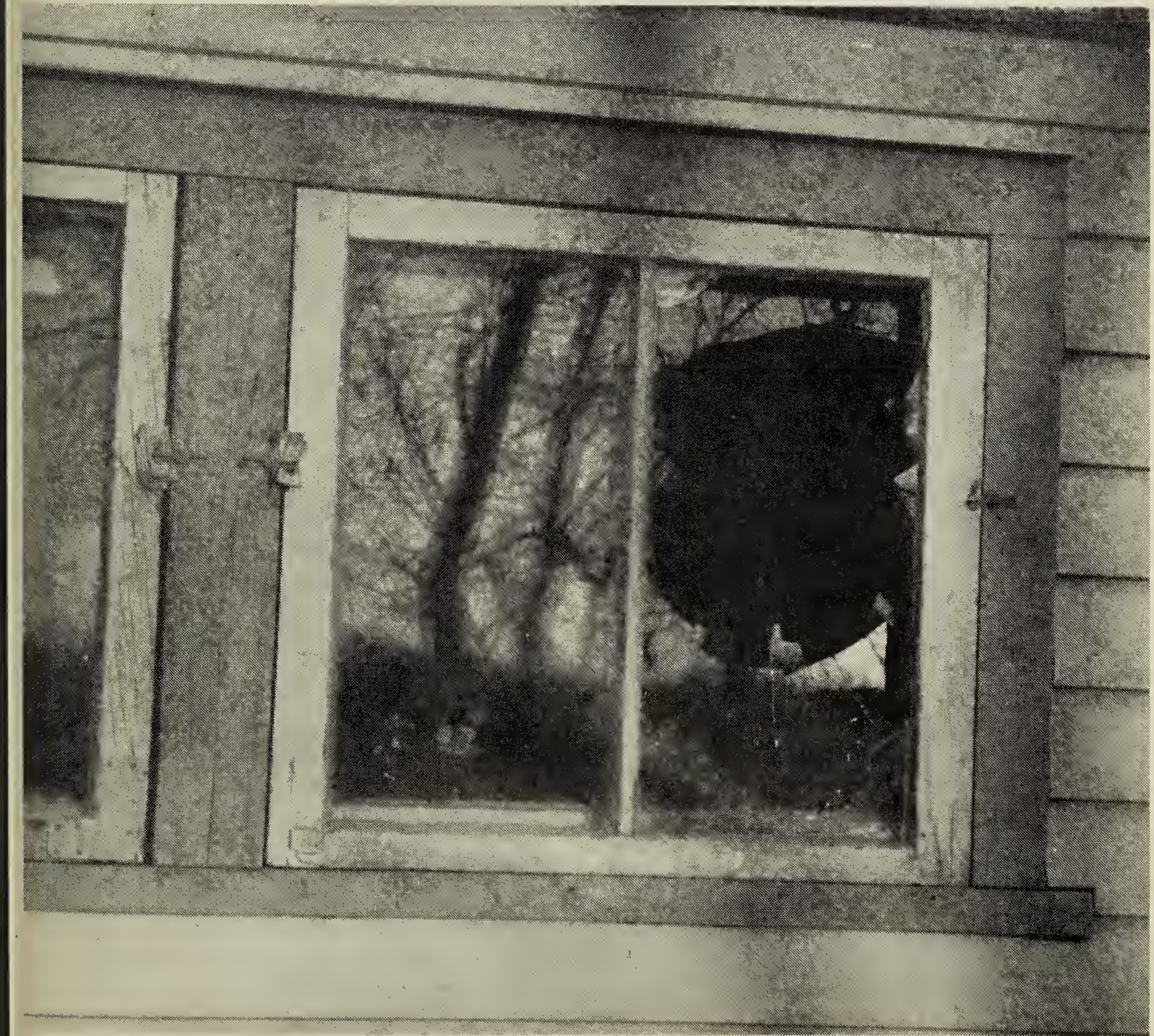


nearby, cleaning up the broken glass, before it got up and walked into the carragana hedge. The eventual fate of this grouse remained unknown. Grouse, when injured, may ultimately die, if not from injuries, then from an unwillingness to eat. ${ }^{2}$ It is to be hoped that the Ruffed Grouse I saw a few days later in our backyard, nipping off rose hips from a briar patch, was our unexpected house guest.

My neighbor's two observations occurred about a dozen years apart. He remembers that sometime in the period 1960-65, in early spring or late fall (there were no leaves on the trees), a Ruffed Grouse landed in his yard after a flight of a few hundred yards from a poplar bush in our pasture. It was mid-morning, and the bird was flying away from the sun. When he walked towards it, it took off again, in a southwesterly direction, and 50 feet away crashed into the north wall of his house trailer

The neighbor found it strange that the bird should do so when the trailer, painted rose, must have bulked large above the skyline from the bird's point of view. Furthermore, the grouse flew against the wall rather than against the large window on that side. The grouse, clucking now, was seemingly unhurt, and when approached, it flew up a second time, straight west through a small stand of trees. It made little attempt to dodge the branches. It seemed to exhibit some of the characteristics of crazy grouse, i.e., because of a kind of harassment, it became increasingly agitated, and, already out of its normal habitat, flew into objects there.

Then on January 21, 1978, at 9:00 a.m., a pair of Ruffed Grouse flew westward into this neighbor's yard, once more from the poplar bush in our pasture. They had been flying there all winter in order to feed on elderberries and so were acquainted with the farmyard. One bird landed in the snow as usual; the other flew against the east window of the house. That the light was still on inside may have affected the bird's vision, but it is hard to believe a grouse would wish to fly into a household of people. Outside, the morning light was good even though the sun was not yet up. The sky was clear, and with no appreciable wind and the thermometer standing at $-18^{\circ} \mathrm{C}$. Hoarfrosted trees added to the brightness.

On other mornings the neighbor had sometimes noticed these same grouse entering the yard by sailing headfirst into soft snow and then crawling out right away to begin their feeding. It seemed to be their customary way of landing.

\section{Conclusions}

The most recent literature on the subject of crazy-flights tends to relate normal fall dispersal to this phenomenon and points to juvenile birds as the most frequent victims. The focus tends to be away from unusual conditions (parasites, diet, etc.) suggested by earlier naturalists. Godfrey and Marshall are foremost in saying that the phenomenon could most readily be explained by the fortuitous combination of dispersing grouse and objects in theif paths. ${ }^{3}$

My own observations, however representative they might be, show that crazy-flights occur during all seasons of the year, with spring, in fact, taking predominance over fall. At least one researcher, cited in my previous article, believed that spring crazy-flights do occur. ${ }^{2}$ Of course, it can be argued that collisions other than in fall are accidental and not true crazy-flights. But this seems to be begging the question, since their very nature is what is under study.

Godfrey and Marshall do speak of the trait as a seasonal activity but at 
the same time suggest that it is more obvious during those falls when there are greater numbers of grouse to be dispersed. Could it not be argued in a similar vein, the dates of my own random observations notwithstanding, that this trait would generally be more obvious any fall than in other seasons because there are peak populations of flying birds - adults and young - in fall? That is, the trait may be a yearround phenomenon, manifested noticeably in fall. Most birds killed would be juveniles if only because there are more of them and they compose the age group which is wandering, seeking new territory. Furthermore, they would not be as wary as older birds

We have seen that grouse can be aggressive and also easily agitated. We are familiar too, with their impulsive flight habits, their taking off like an exploding bomb (with speeds up to 51 miles per hour ${ }^{5}$ ) and their sailing headfirst into snowbanks with seeming abandon. Both characteristics have stood the bird in good stead in its wild habitat, either in bluffing or intimidating its enemies or in escaping from them. A grouse typically flies in a straight line and close to the ground. What little manoeuverability it has is usually sufficient to dodge trees in its path, but man-made obstructions, being as long and wide as they are, require more greater agility in flight. In a farmyard a slight veering to one side may not prevent collisions with a building. Witness the grouse described earlier which could steer its course safely between two rows of trees but could not avoid hitting our house.

While I can still say, as I did in my previous article, that "more details of the circumstances surrounding this curious phenomenon need to be recorded in the future," it may well be that the final explanation is simpler than was first supposed.
'CHAMBERS, R. E., and W. M. SHARP. 1958. Movement and dispersal within a population of Ruffed Grouse. J. Wildl. Manage. 22:231-239.

${ }^{2}$ FRIESEN, V. C. 1971. The crazy flight phenomenon of the Ruffed Crouse. Blue Jay 29:121-124.

${ }^{3}$ GODFREY, G. A., and W. H. MARSHALL. 1969. Brood break-up and dispersal of Ruffed Grouse. J. Wildl. Manage. 33:609620 .

${ }^{4}$ HALE, J. B., and R. S. DORNEY. 1963 Seasonal movements of Ruffed Crouse in Wisconsin. J. Wildl. Manage. 27:648656.

${ }^{5}$ RUE, L. L. 1973. The World of the Ruffed Grouse. J. B. Lippincott, Philadelphia. $160 \mathrm{pp}$.

${ }^{6}$ SETON, E. T. 1977 (originally published 1898). Wild Animals I Have Known. McClelland and Stewart, Toronto. 298 $\mathrm{pp}$.

TTRIPPENSEE， R. E. 1948. Wildlife Management: Upland Game and General Principles. Vol. 1. McGraw-Hill, New York. 479 pp.

${ }^{8}$ WOOLNER, F. 1970. Grouse and Grouse Hunting. Crown Publishers, New York. $192 \mathrm{pp}$.

\section{SASKATCHEWAN CHRISTMAS BIRD COUNT}

From Saturday, December 16, 1978 to Monday, January 1, 1979 inclusive. Count area should be a circle, $24 \mathrm{~km}$ (15 miles) in diameter. This year, bird count forms will be sent to all compilers who submitted counts for Christmas 1977. Anyone else who wishes to send in a count, please write for a form to: Mrs. Mary I. Houston, 863 University Drive, Saskatoon, Sask. S7N 0J8.

Reports should be sent as soon as possible after the count (by January 12, 1979 at the latest) to the above address. 